\title{
A favor y en contra de la Historia El cine moderno y el pueblo que falta o el derrumbe de los esencialismos
}

\author{
Irene Valle Corpas
}

Recibido: 30.10.2019 - Aceptado: 29.11.2019

\section{Titre / Title / Titolo}

Pour et contre l'histoire. Le cinéma moderne et le peuple disparu ou l'effondrement des essentialismes

For and Against History. Modern cinema and the missing people or the collapse of essentialism

A favore e contro la storia. Il cinema moderno ed

il popolo scomparso, o il crollo dell'essenzialismo

\section{Resumen / Résumé / Abstract / Riassunto}

El frescor de las nuevas olas comenzó en realidad como un soplo de memoria y de Historia. Para una generación de cineastas de los sesenta, la irrupción de la Modernidad no debía llevar a la desmemoria, el culto a lo fugaz o lo deslocalizado. Contrariamente, trabajando con los restos de la IIGM y en un clima de fuertes tensión geopolítica, recelosos, tales cineastas, sobre todo en europeos, no quisieron olvidar las heridas pasadas o presentes, y las reabrieron contra el consenso amnésico ínsito a los días de «progreso». Se propusieron criticar los grandes ideales que en el horizonte de las grandes transformaciones sociales de posguerra empezaban a marchitarse y apelaron a la creación con imágenes de otros nuevos.

La fraîcheur des nouvelles vagues a commencé comme un souffle de mémoire et d'histoire. Pour une génération de cinéastes des années 60 , l'irruption de la modernité ne devrait pas conduire à la démémoration, au culte de l'éphémère ou de la délocalisation. Au contraire, travaillant avec les restes de l'IIGM et dans un climat de forte tension géopolitique, méfiants, ces cinéastes, surtout en Europe, ne voulaient pas oublier les blessures passées ou présentes, mais les rouvrir contre le consensus amnésique inhérent aux jours du «progrès». Ils se sont mis à critiquer les grands idéaux qui commençaient à se faner dans l'horizon des grandes transformations sociales de l'après-guerre et ont fait appel à la création de nouveaux avec images.
The freshness of the new waves actually began as a breath of memory and History. For a generation of filmmakers in the sixties, the irruption of Modernity should not mean forgetfulness, the cult of the ephemeral or the delocalised. On the contrary, working with the remains of the IIGM and in a climate of strong geopolitical tension and major social changes, especially in Europe, such filmmakers, distrusting, did not want to forget past or present wounds, they re-opened them against the amnesic consensus inherent of the days of "progress". They set out to criticize the great ideals that began to wither on the horizon of the great social transformations of the post-war period and pleaded for the creation of new ones through the use of images.

La freschezza dei 'nuovi cinema' cominciò come un soffio di memoria e di storia. Per una generazione di cineasti degli anni Sessanta, l'irruzione della modernità non avrebbe dovuto portare alla dememoria, al culto del'effimero o del delocalizzato. Al contrario, lavorando con i resti della IIGM e in un clima di forte tensione geopolitica, questi cineasti, soprattutto in Europa, non hanno voluto dimenticare le ferite passate o presenti, e le hanno riaperte contro il consenso amnesico proprio del periodo del "progresso". Si proponevano di criticare i grandi ideali che cominciavano a svanire all'orizzonte delle grandi trasformazioni sociali del dopoguerra e appellavano alla creazione di nuovi ideali mediante l'uso di immagini.

\section{Palabras clave / Mots-clé I Key words / Parole chiave}

Nuevas olas, años sesenta, memoria, Jean-Luc Godard, Pier Paolo Pasolini. Nouvelles vagues, mémoire, années soixante, Jean-Luc Godard,

Pier Paolo Pasolini.

New Waves, memory, sixties, Jean-Luc Godard, Pier Paolo Pasolini.

Nuovi cinema, memoria, anni Sessanta, Jean-Luc Godard,

Pier Paolo Pasolini.

Este trabajo se realiza gracias a una beca del Ayuntamiento de Madrid para investigadores y artistas en la Residencia de Estudiantes de Madrid. 


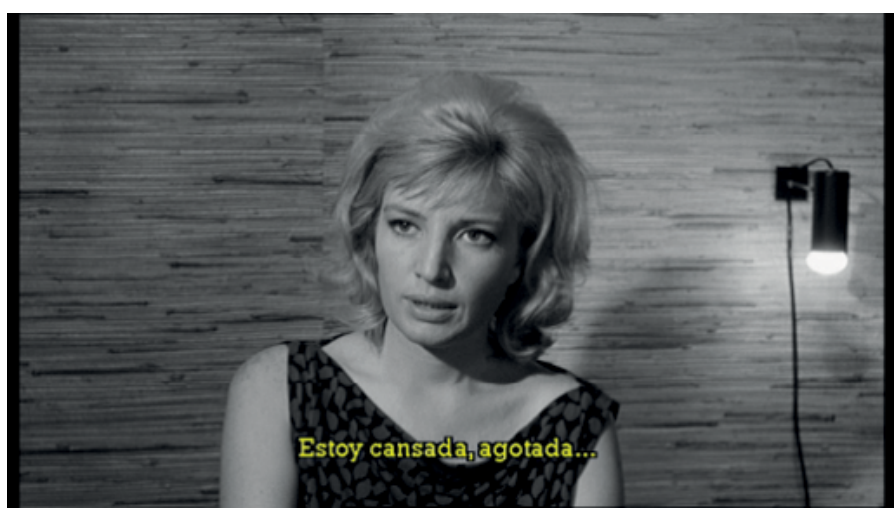

Figura 1

«Estoy cansada, agotada, asqueada, desorientada...», confesaba Vittoria (Monica Vitti), personaje central de Eleclipse (L'eclisse, 1962) que pasea su apatía por el encuadre de Michelangelo Antonioni, sin descanso pero sin encontrar consuelo [Fig. 1]. Ni ella ni tanto menos el espectador sabrán a ciencia cierta las razones que motivan su indolencia. Tan solo sabemos que esta atonía vital no se cura. De hecho, persistirá. «Hay algo terrible en la realidad y no sé lo que es» intuía una asustada y quebradiza Giuliana, también interpretada por Vitti en mitad de la densa niebla de El desierto rojo (Il deserto rosso), ese otro concentrado de angustia que rodara el de Ferrara en 1964 [Fig. 2]. Menos brumosa y lánguida, antes bien enérgica, pero igualmente «golpeada» por las circunstancias, Paula Nelson (Anna Karina), la detectivesca protagonista de Made in U.S.A. (Made in U.S.A., Jean-Luc Godard, 1966) merodea por una ciudad de cartón piedra que hace las veces de mundo en pequeñito. Ella también

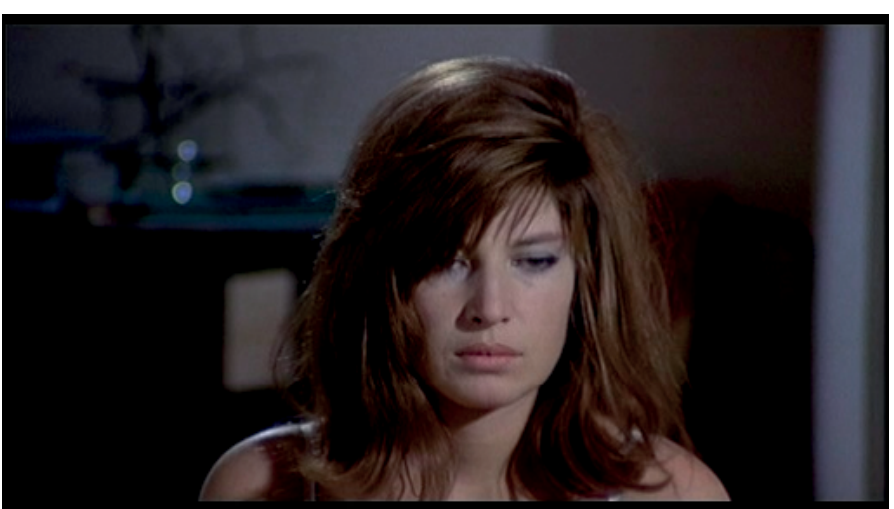

Figura 2 advierte ese «algo terrible» que hay en la realidad, ante el cual ya no solo siente desconcierto sino sobre todo una profunda repulsión: «¿Cómo es que no vomito de estar en este mundo?» [Fig. 3]. Quizá su náusea se manifestase en el momento en el que Paula percibiese ese mismo «olor a muerte» que un año antes notara Pierrot el loco, el arlequín guerrillero que se da a la fuga de un París irrespirable en la cinta homónima de Godard.

Por las galerías subterráneas de ese mismo París de náusea ya había andurreado Chris Marker para rodar El muelle (La jetée, 1962), una fábula distópica que como se sabe bien, discurre en torno a «la historia de un hombre marcado por una imagen de la infancia», pero que, si bien se recuerda con menor frecuencia, era también la historia de «un hombre que tiene miedo» [Fig. 4]. Miedo de las secuelas que ha podido dejar una especie de tercera guerra mundial en el aire envenenado de la ciudad, miedo de los hombres extraños que por allí lo buscan y, sobre todo, miedo de no poder habitar el tiempo en ese futuro que sigue a la devastación y que para él, aunque sea «futuro» es ya totalmente póstumo. Un año después con La rabia (La Rabbia, 1963), un film ensayo de carácter «poético y político», Pier Paolo Pasolini se coronaría como el mejor representante de este grupo de seres que huelen y sienten el malestar de forma privilegiada, abriendo su pieza con la siguiente pregunta: «¿Por qué nuestra vida está dominada por el descontento, por la angustia, por el miedo a la guerra, por la guerra?» [Fig. 5]. Toda su obra fue un intento por responder a esta preocupación, aunque la consecuencia esencial que de

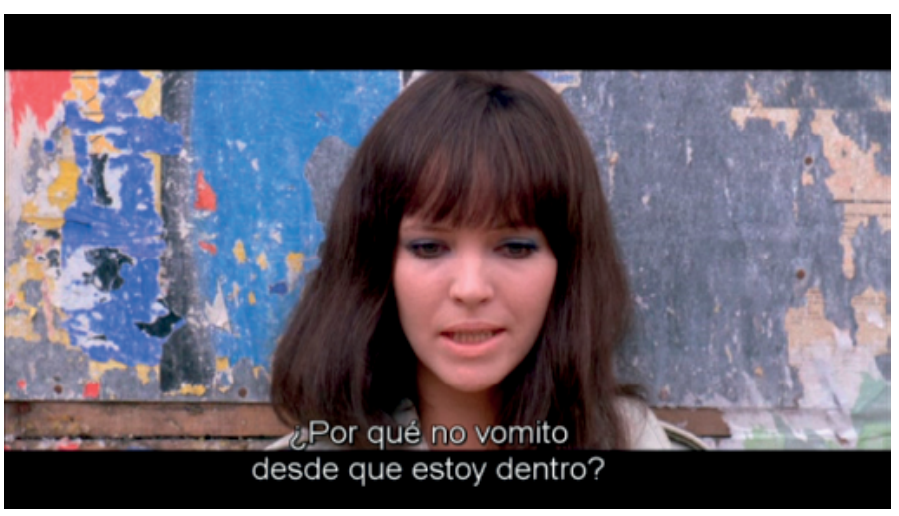

Figura 3 


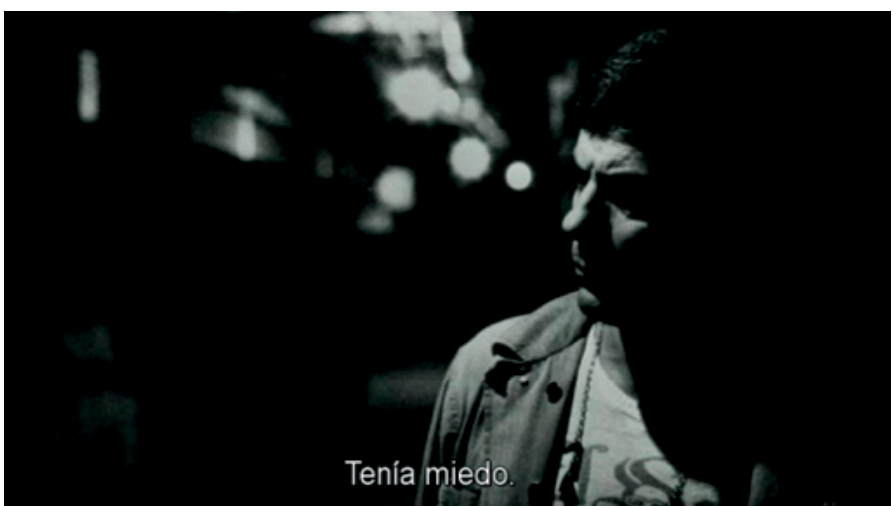

Figura 4

ella se derivaba ya la había extraído antes, en 1961: «En este mundo ya no se puede vivir, hay que sacar la uñas» concluía tajante Accattone, el héroe subproletario de su opera prima y que como todos los personajes del universo pasoliniano, existe (aunque morirá en el intento) solo para advertirnos de los infortunios que nos sobrevienen, mas nadie pareció prestarle oídos, ni entonces ni después [Fig. 6].

En efecto, lo primero que encontramos cuando abrimos las páginas de cualquier libro, novela o ensayo datado en los años sesenta, o cuando volvemos a pasar las cintas de los nombres principales de las nuevas olas, es una sucesión de figuras del Apocalipsis, con lo que toparíamos era con cadáveres de cualquier tipo y estados mentales desasosegados. Asco, angustia, desorien-

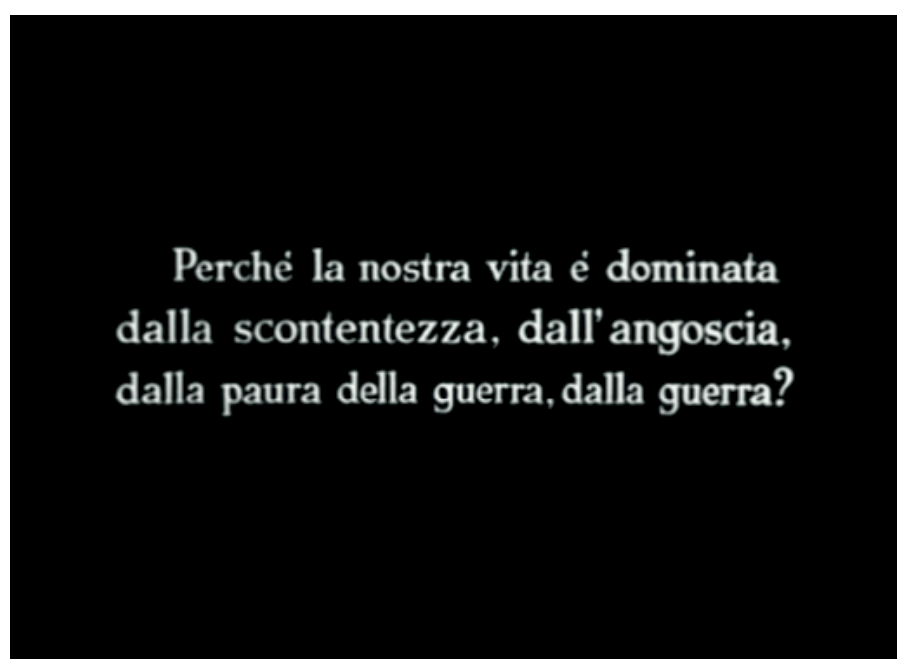

Figura 5 tación, rabia, miedo, descontento, falta de vida, acostumbrémonos a estas palabras, familiaricémonos con estas emociones pues son más que usuales, obsesivas, a lo largo de los años sesenta, a pesar de que este decenio haya pasado a nuestro imaginario colectivo como el más festivo y celebratorio de la centuria. En Pasolini, Antonioni, Rohmer, en Vardà, Buñuel, Godard o Marker conceptos como los de Pueblo, Utopía, Historia, Sujeto, Sociedad Vida o Libertad serían drásticamente reconsiderados, puestos en tela de juicio y en algunos casos dados por muertos. Se los habría llevado consigo una expansión económica sin precedentes del campo y la ciudad con los consiguientes flujos migratorios internos (de sur a norte y de las zonas agrícolas a las fabriles), así como la descolonización e industrialización del Tercer Mundo. Y todo ello en un globo que presentaba una división en bloques antitéticos, llegando a amenazar con diluir la organización política vigente hasta entonces en la mayoría de países, a saber, el Estado-Nación con proyectos como los del Plan Marshall.

Tomando algunos nombres y ejemplos escogidos al vuelo, en este artículo haremos un repaso por ese impulso crítico que caracteriza el cine moderno en Europa y que lo llevaría a no querer fiarse de nada, a sembrar dudas sobre imágenes capitales del ideario humanista de posguerra, a fin de reconstruir el mundo en formas más auténticas, esto es, más pegadas a la vida real de las

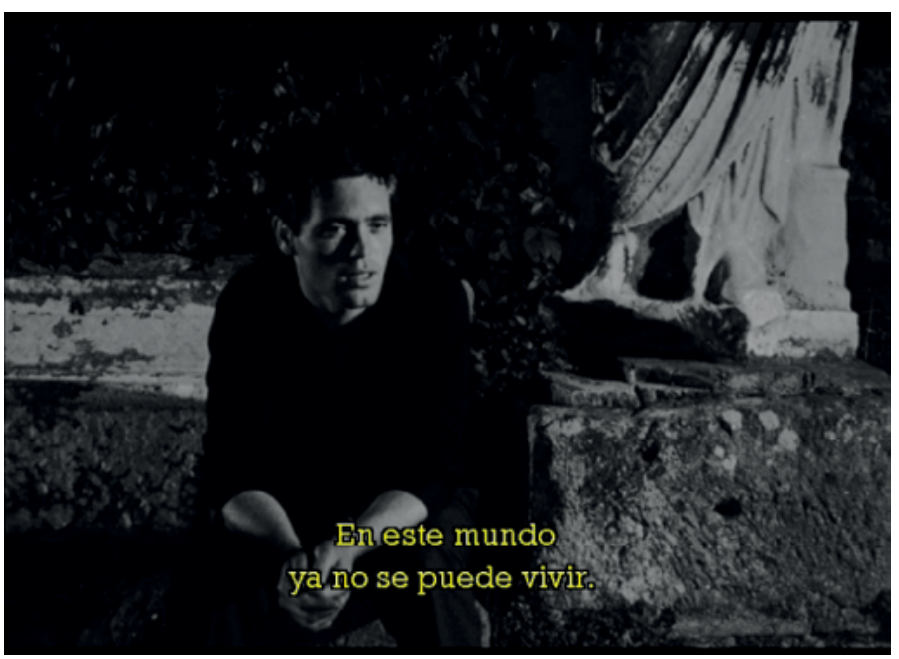

Figura 6 
clases populares y más liberadoras para ellas. Nuestra intención es comprobar hasta qué punto la impugnación y la crisis del mundo y el paisaje social del desarrollismo que asociamos con el episodio de revueltas en torno a Mayo del 68, era, sin embargo, perfectamente reconocible en las pantallas de los realizadores y en los albores mismos de dicha etapa histórica.

Podemos comenzar recordando que en 1960 el sociólogo norteamericano Daniel Bell publicó su influyente ensayo El fin de la ideología en el que constataba el devenir pragmático y consensual que había tomado la política de su país y por extensión del mundo occidental en la última década. En su país, el también sociólogo Herbert Marcuse, poco antes del estallido de los movimientos hippie y juvenil, anunciaba que la lucha antisistémica no podía estar ya guiada por ningún movimiento de masas al estar éste formado por ese nuevo sujeto gris y totalmente absorbido por el sistema que constituía el «hombre unidimensional»: «Las clases trabajadoras en las zonas avanzadas de la civilización industrial están pasando por una transformación decisiva. [...] El "pueblo" que anteriormente era el fermento del cambio social, se "ha elevado" para convertirse en el fermento de la cohesión social» (Marcuse, 1953: 58 y 285). Andy Warhol, quizá el personaje más lúcido y con la mirada más directa de la Norteamérica de los sesenta, parecía darles la razón complacido, como si tal consenso en torno a esta falta aparente de sustantividad, fuera una buena nueva:

Warhol- Alguien dijo que Brecht quería que todo el mundo pensara de la misma manera. Yo también quiero que todo el mundo piense de la misma manera. Pero Brecht pretendía llegar a eso por el comunismo. Rusia lo está haciendo mediante el gobierno: aquí está sucediendo sin intervención de un gobierno fuerte. Entonces, si funciona sin proponérselo, ¿por qué no habría de funcionar sin ser comunista? Todo el mundo se ve de la misma manera y actúa de la misma manera. Todo el mundo debería ser una máquina. Todo el mundo debería actuar como todo el mundo.

Entrevistador- ¿A eso apunta el pop art?

Warhol- Sí, tiene que ver con igualar las cosas.

(Tomado de Huyssen, 2006: 257)

(Bell, 1992).
En la aceptación a primera vista sin fisuras por parte de algunos artistas de este fin de la ideología como freno a la igualación humana, autores como Pasolini veían una apología a la pasividad impuesta por la burguesía a uno y otro lado del Atlántico. Quizá por eso sea precisamente la Ideología el país de donde provenía el cuervo parlante que interrumpe a Ninetto y Totò, padre e hijo respectivamente, en su caminata por los polvorientos campos y senderos de la periferia romana en esa fábula política que es Pajaritos y pajarracos (Uccelacci e uccellini, 1966). En la cinta de Pasolini, este pájaro vestido de luto y algo cascarrabias, dice ser hijo de la Duda y la Conciencia y venir de este país perdido, donde habita en la calle Carlos Marx, número 70 veces 7 . El pájaro ruega a unos pobretones de suburbio romano con los que se encuentra que le dejen andar con ellos, ser su compañero de ruta (compagno di strada), pero antes, como es normal, quiere saber a dónde se dirigen: «A la derecha? ¿A la izquierda? ¿Recto?». En vista de que Totò y Ninetto siguen su andar hacia delante sin escucharle ni responder a sus preguntas, este cuervo de aire lastimero y piquito de oro, no deja de filosofar, contar parábolas o soltar inmisericordemente, sentencias categóricas con las que él mismo se responde: «Han pasado de moda las ideologías y aquí queda uno hablando ya no se sabe de qué a unos hombres que van, no se sabe a dónde». En efecto, los otros dos, por su puesto, ni caso. A final del camino, el pájaro que se dice profeta (aunque a Ninetto y Totò les recuerde más bien a un policía), declarará sus últimas palabras antes de ser devorado por sus acompañantes: «El camino comienza y el viaje ya ha terminado».

No sería la única vez en el cine de Pasolini que seamos invitados a seguir los pasos de una extraña pareja compuesta por alguien que habla sin cesar y otro que hace oídos sordos a cuanto se le dice y cuyos pasos, al final del camino, nos conduzcan hacia una muerte irremediable. Eso es justo lo que le ocurre a Ninetto, el jovenzuelo danzante que de nuevo encarna al pueblo feliz y despreocupado de la Italia de finales de los sesenta en el cortometraje Secuencia de la flor de papel (La sequenza del fiore di carta) e integrado en la obra coral Amor 

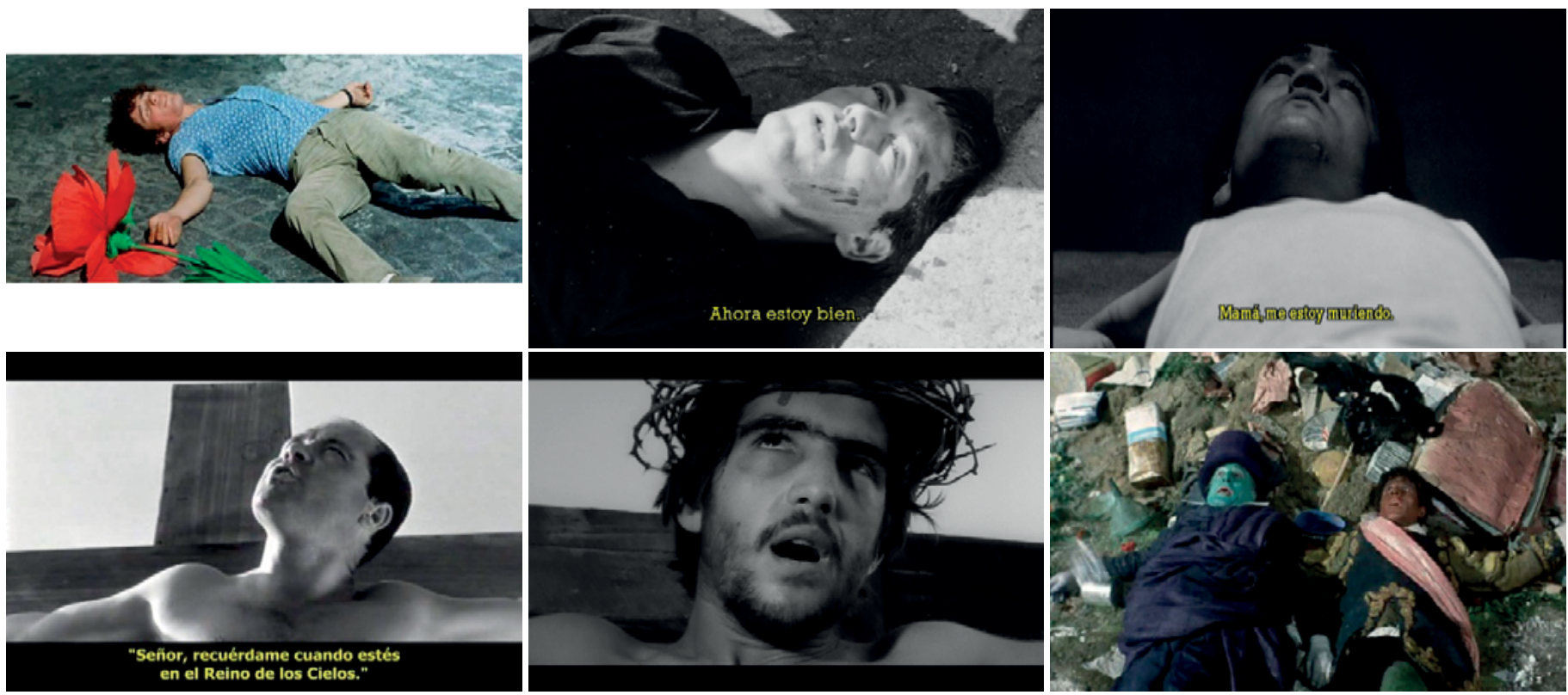

Figura 7

y rabia (Amore e rabbia, Bellochio, Bertolucci, Pasolini, Godard, Lizzani, 1969). Otra vez, Ninetto andurrea por una larga vía siendo interpelado por una voz, esta vez, la mismísima palabra de Dios que trata de arrancarlo de su inconsciencia: «Non mi senti? Sei sordo?» Al final de su caminata Ninetto, a quien le importa un bledo lo que entona la voz misteriosa, morirá sin entender nada, sin que su sonrisa se borre siquiera, caerá, con los brazos en cruz, sin darse mucha cuenta de qué le ha podido sobrevenir, pero muerto al fin y al cabo. Muerto como todos aquellos que le precedieron: como Accattone, como el Ettore de Mamma Roma (1962) que acaba sus días como un Jesús doliente de Mantegna en un sanatorio de suburbio, como lo hará Stracci en La Ricotta (1962) quien también exhala su último aliento en una cruz de madera, la misma que luego acogerá la muerte de Cristo en El evangelio según San Mateo (Il Vangelo secondo Matteo, 1964), muerto como lo hará la pobre criada de Teorema (1968) que asciende a los cielos como una santa y luego es enterrada y como le ocurrirá a los dos pobretones de ¿Qué son las nubes? (Che cosa sono le nuvole,1968) que son arrojados a la basura ya sin vida. Ninetto acaba muerto como todos los raggazzi di vita que las pierden, como las pierden sus cuervos-profetas que dudan y sus
Cristos rebeldes a los que nadie atiende [Fig. 7]. Con la muerte del pueblo, de la ideología y de la consciencia, así es como empieza y acaba la década para Pasolini. No resulta extraño entonces que asegurase encontrarse a la deriva, se sabe «expulsado del futuro», «amando el mundo que odio», porque hace tiempo que nadie quiere escucharlo y se siente solo, «solo como un cadáver en la morgue» ${ }^{2}$.

Salvando las distancias pero en franca correspondencia con este sentir, este es el mismo escenario que encontramos en uno de los grandes films de Resnais, que abordan el problema de la memoria y la inserción del ser en la Historia. Nos referimos a La guerra ha acabado ( $L a$ Guerre est finie), una película algo anterior, de 1964, con guión de Jorge Semprún. En los años sesenta, en pleno momento de «aperturismo» de la dictadura franquista, un miembro del Partido Comunista Español afincado en París, realiza incursiones clandestinas a España para organizar las actividades de la resistencia. Sobrevive inventando falsas vidas y nombres en clave, y saltando de amante en amante, de ciudad en ciudad, de un arrabal periférico a otro no menos gris (los H.L.M de Ivry o

2 Versos tomados de (Pasolini, 1997). 
Aubervilliers donde vivían los refugiados españoles). En un momento dado, invadido por la rabia, explota:

A nadie le gustaría saber lo que tengo que decir sobre España. $\mathrm{Ni}$ siquiera yo estoy seguro de que me guste. La pobre, infeliz España, la España heroica. Estoy harto. España se ha convertido en la buena conciencia lírica de la izquierda. Un mito para veteranos de guerra. Mientras 14 millones de turistas pasan en España cada año sus vacaciones. España no es más que un sueño para los turistas o la leyenda de la Guerra Civil. [...] España ya no es el sueño del 36 sino la verdad de 1965, aunque sea desconcertante.

La guerra ha acabado es un film totalmente reflexivo, carente de «acción» en una extraña mímesis con la situación política de Europa a mediados de los sesenta. Las huelgas se anuncian y se esperan pero «todo se mueve y nada cambia» ${ }^{3}$. En esta, como en tantas cintas del momento, la crisis de la izquierda y sus intelectuales pasa por la crisis personal de los personajes. Carlos, como Fabrizio, el joven protagonista de Antes de la revolución (Prima della Revoluzione, Bernardo Bertolucci, 1964) [Fig. 8], también tiene «nostalgia del presente». Sabe que

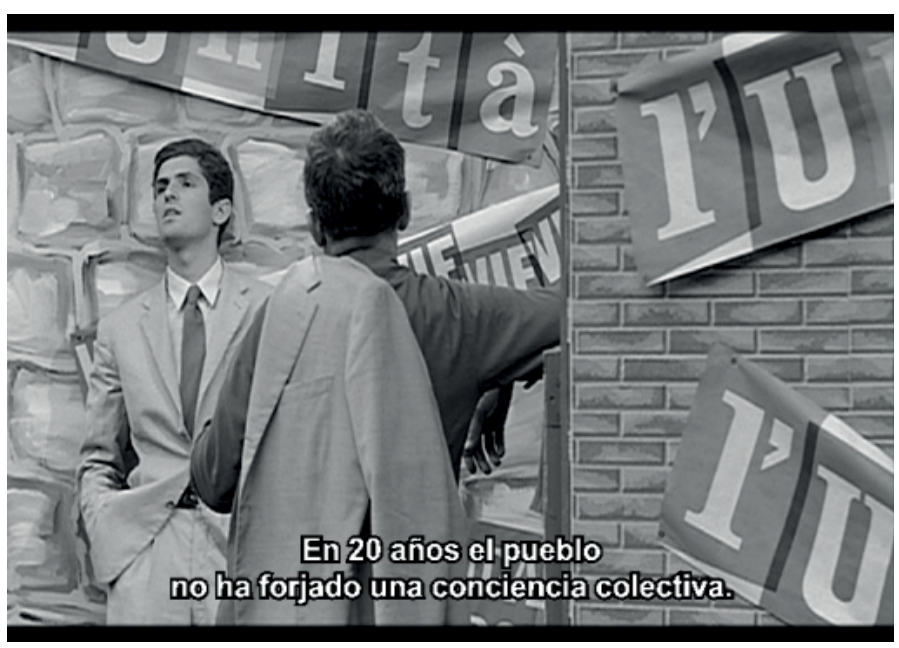

Figura 8

${ }^{3}$ Recordemos, como comenta Nuñez Laiseca, que 1962 marca el comienzo de la erosión del consenso social interno que se había procurado el régimen y que terminaría por romperse a partir de la recesión económica de 1967. En 1963 se produce un levantamiento minero al que le siguieron diversas protestas a lo largo de los años - contra la Ley de Prensa e Imprenta, la instalación de bases militares estadounidenses, el confinamiento de los presos políticos en la cárcel de Burgos, etcétera- que van generando un cada vez más intenso clima de protesta y activismo político, al que el régimen respondió con una represión de simétrica intensidad. (Laiseca, 2006). la Historia va en una dirección opuesta a lo esperado y que el pueblo al que apela (en el caso de Bertolucci, la clase obrera italiana y en Resnais, la España popular de antes de la guerra), está absolutamente ausente — desaparecido también de la pantalla, pues en ambos casos se convoca y se describe a un sujeto que jamás aparece en el film-. O sea que además de sordo y muerto el pueblo era un fantasma.

En escasos años, decimos, los más elevados ideales y las más grandilocuentes palabras empezaban a oxidarse - $\mathrm{O}$ incluso a pudrirse - en su contacto con un corrosivo y homogeneizante poder del mercado, tanto para homologar a las clases como para lavar la memoria. Como el de pueblo, otro de esos nobles principios que se amarillean y despiertan el recelo de los intelectuales es el de Paz. En 1957 el gobierno franquista, ya entonces convertido en una camarilla de tecnócratas del Opus Dei, había conseguido ingresar en la OECE y el FMI sin grandes trabas diplomáticas y celebraba sus «25 años Paz». Para algunos era más que obvio, por tanto, que la «Paz de Franco», se parecía demasiado a la «Pax americana, lavado de cerebro súper económico» que Godard denunciara en Dos o tres cosas que sé de ella (Deux ou trois choses, 1967), o sea, una forma de ocultación de los crímenes cometidos y de la miseria política del presente, bajo la bandera del crecimiento y al auspicio de los programas económicos norteamericanos [Fig. 9]. Muchos vieron en los discursos sobre la paz ante todo una llamada colectiva a exorcizar cualquier elemento cuyo recuerdo pudiera enturbiar el pacífico progreso, ya proviniese del presente o del pasado. Paz definía un estado de falsa tregua, de sometimiento acallado y violencia velada que por mucho que el estado se obstinase en disipar, eventualmente (y pongamos por caso que lo hizo al término de la década) estallaría. Para muchos, paz era una palabra que actuaba como fachada de una situación menos equilibrada. Con el andar de los años las llamadas al litigio y al combate se sentirán cada vez más improrrogables. Se hará necesario denunciar el consenso social como el lado opuesto a la política e introducir sujetos nuevos. Se irá gestando una suerte de rabia que acaba en llamada a la agitación y la violencia contra todo pilar intocable del edificio social. 

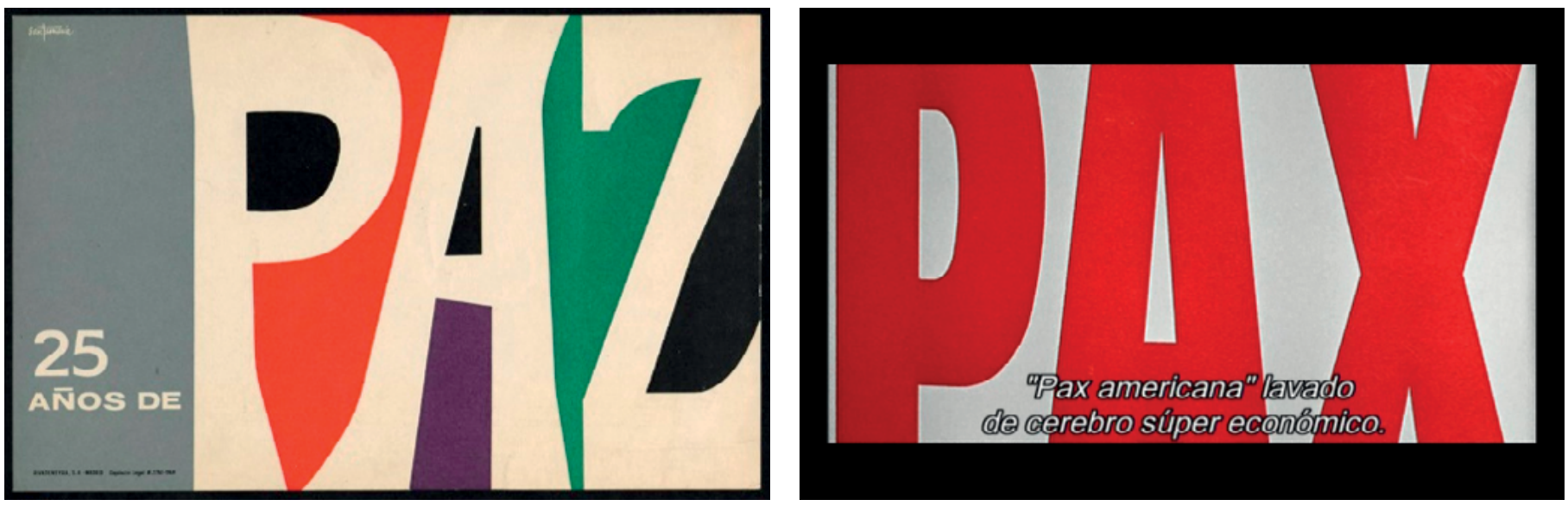

Figura 9
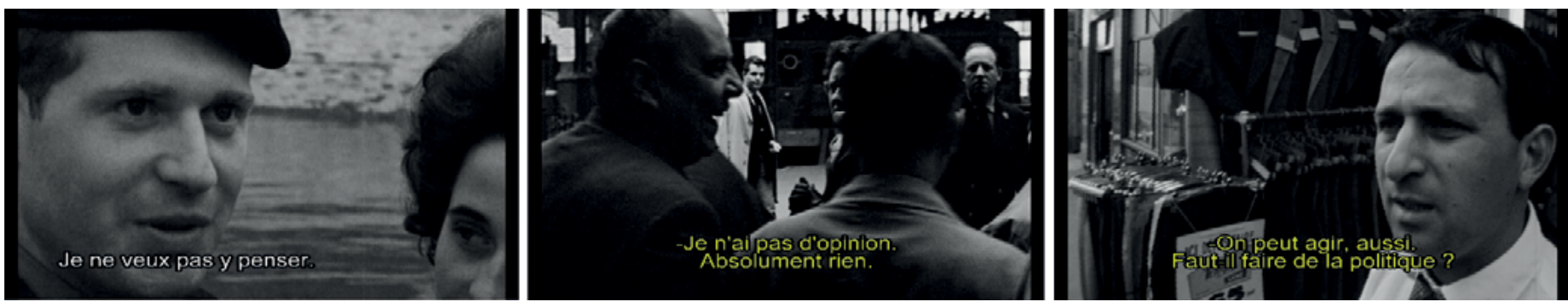

Figura 10

Hasta entonces, durante los años sesenta, en distintos ejemplos podemos comprobar que «paz» —una palabra que con suerte podía pronunciarse solo en Europa y los EE. UU. - se convertirá en sinónimo de un deseo de olvido colectivo, del estatismo y de la imposición del silencio. Esta afirmación cobra su sentido si se acuden a los primeros minutos de Le Joli Mai subtitulados «escenas que ocurren en el mes de mayo de 1962, la primera primavera de la paz». En ellos los directores Chris Marker y Pierre Lhomme entrevistan a ciudadanos escogidos un poco al azar sobre qué posible significado pueden tener para ellos esas dos palabras, paz y felicidad, por entonces tan cacareadas. Las respuestas son directas: comer bien, dormir bien y buscar un hueco en esa gran ciudad y en esos nuevos tiempos que se abren. Los realizadores les instigan a que digan más, a que profundicen en sus planas respuestas, a que den su verdadera opinión sobre los problemas y conflictos reales que subsisten. Es en sus pequeñas quejas, en sus silencios incómodos y sus negativas a hablar de política donde podemos leer los recelos, el descontento, el miedo, donde podemos ver que esa paz medrosa estaba llena de grietas y tan solo era muda en apariencia [Fig. 10]. Otros simplemente se reían recordando que Pax no era más que el nombre de una marca de lejía ${ }^{4}$.

«¿Por qué negar la necesidad evidente de memoria?», ¿por qué negar que el dolor aún permanece en el recuerdo? inquiría por su parte Marguerite Duras, en el guión para Hiroshima mon amour, película dirigida por Alain Resnais que daría en 1959 el pistoletazo de salida a esa modernidad cinematográfica ${ }^{5}$. «Me olvido de Hiroshima, de Auschwitz, de Budapest, del Vietnam, del salario mínimo, de la crisis de la vivienda, del hambre en la India. Lo he olvidado todo. Salvo que como me llevan al principio de todo, desde ahí deberé empezar de nuevo». Así presentaba Godard al espectador y a sí mismo, con cierta ironía y otra dosis de pesadumbre, la

\footnotetext{
${ }^{4}$ Veáse la entrada sobre la Lejía Pax en (Baudrillard, 1970: 202-204). ${ }^{5}$ Hemos analizado esto en (Valle y Arozamena, 2018).
} 
situación precaria e indiferente de relación con el dolor de los otros y con aquel amontonado en la memoria reciente en que la sociedad de consumo había sumido a sus ciudadanos en la citada Dos o tres cosas que sé de ella. Por eso cabía la posibilidad de que tales palabras rescatadas del pasado fueran empleadas en una vuelta de hoja, para describir el presente como una simple extensión de los errores dado un contexto nuevo. Por ejemplo, si a Pasolini la Democracia Cristiana se le antojaba una prolongación del proyecto de Mussolini y no se mordió jamás la lengua al hablar de «neofascismo», para Godard el término «Ocupación» encontraba un nuevo sentido en el contexto de entrega sistemática del tiempo de vida y la subjetividad de la gente a la producción, que tendrá su correlato en la expropiación de cada vez más enclaves de la ciudad. Denunciará entonces, como hizo en sus ensayos fílmicos de mediados de la década una «Ocupación» a color, hecha con grúas, imágenes y deseos, pero igualmente invasiva.

Al historizarla, «Libertad» era otro de esos nobles principios que en su vieja formulación ya no encontraban encaje sencillo en este nuevo paisaje social porque era utilizada con fines denigrantes en el clima de la Guerra Fría o parecía no tener ya mucha sustancia real. Volvamos a Accattone, esa tragedia de descampado, y recordemos el momento en el que su miserable protagonista, ladrón y proxeneta, completamente desahuciado por las circunstancias, se sienta un instante y afirma: «soy un ciudadano libre» [Fig. 11]. El espectador no puede más que pensar en que tal estatuto no va a mejorar en nada su indigencia vital. Es libre para vagabundear y morirse de hambre, poco más. En Vivir su vida (Vivre sa vie, Jean-Luc Godard, 1962), Nana, una humilde chica de provincias que acaba ejerciendo la prostitución en las calles de París para poder pagar la renta, también hace un discurso sobre la libertad y la autodeterminación aunque las cosas de las que dice ser responsable son tan poco trascendentales y su vida, esa de la que es dueña y libre de vivir, vale tan poco que el discurso es en realidad una negación de sí mismo [Fig. 12]. Su libertad es la misma libertad que encontraremos en los carteles entré libre de Dos o tres cosas que sé de ella, una libertad para

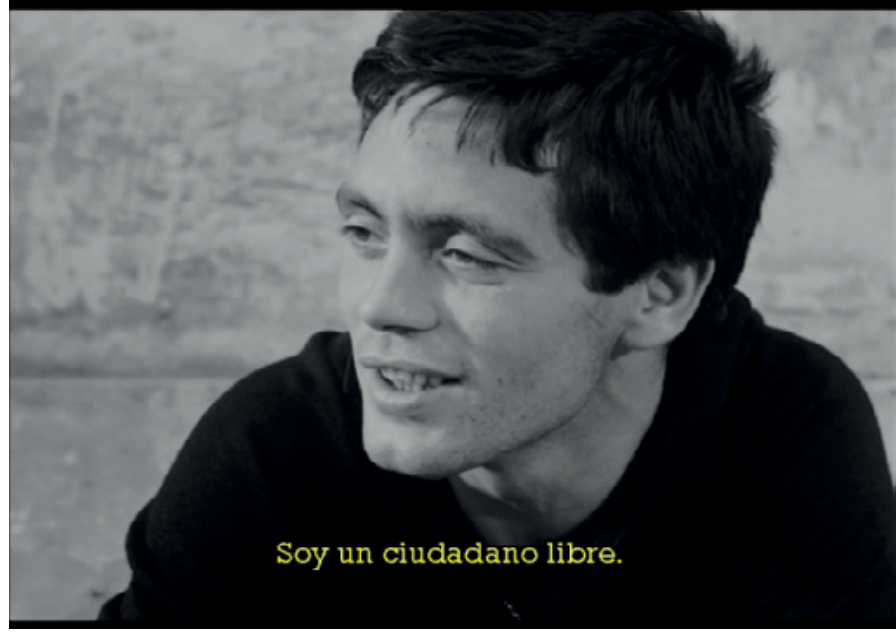

Figura 11

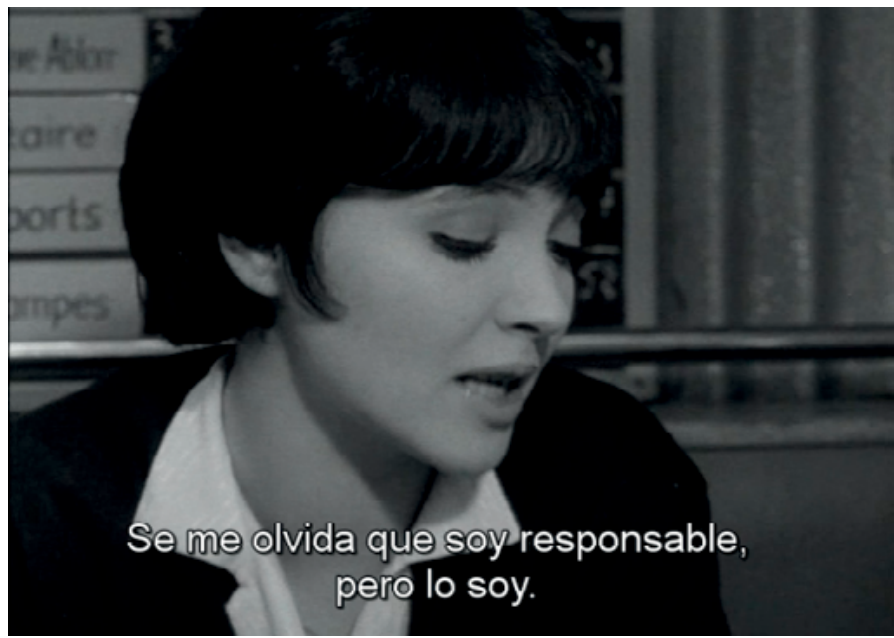

Figura 12

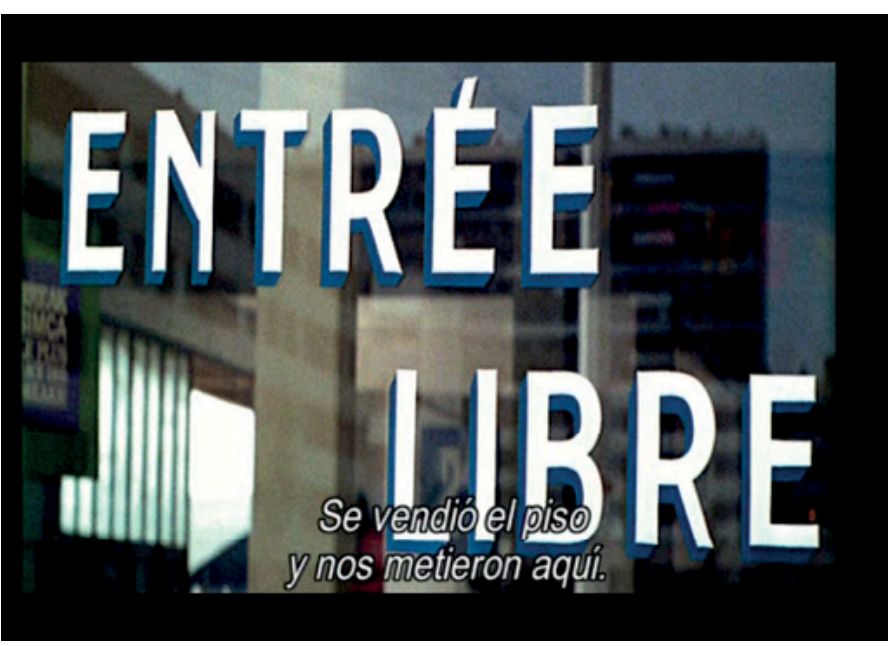

Figura 13 
consumir los días en un suburbio monótono y venderse como prostituta al mejor postor [Fig. 13]. Una libertad tan nimia como la que goza el vendedor que aparece al comienzo de Le Joli Mai, que dice trabajar de nueve de la mañana a ocho de la tarde, y solo entonces al volver a casa, se siente «libre» para no pensar, ver la televisión y discutir con su mujer.

Por supuesto, no se trata de que Godard y sus camaradas no crean en la libertad tal y como tradicionalmente se ha definido este supuesto pilar de la democracia y la cultura occidental, esto es, como una búsqueda de la independencia y autodeterminación de los sujetos con respecto a sus actos, vale decir, una liberación de sus

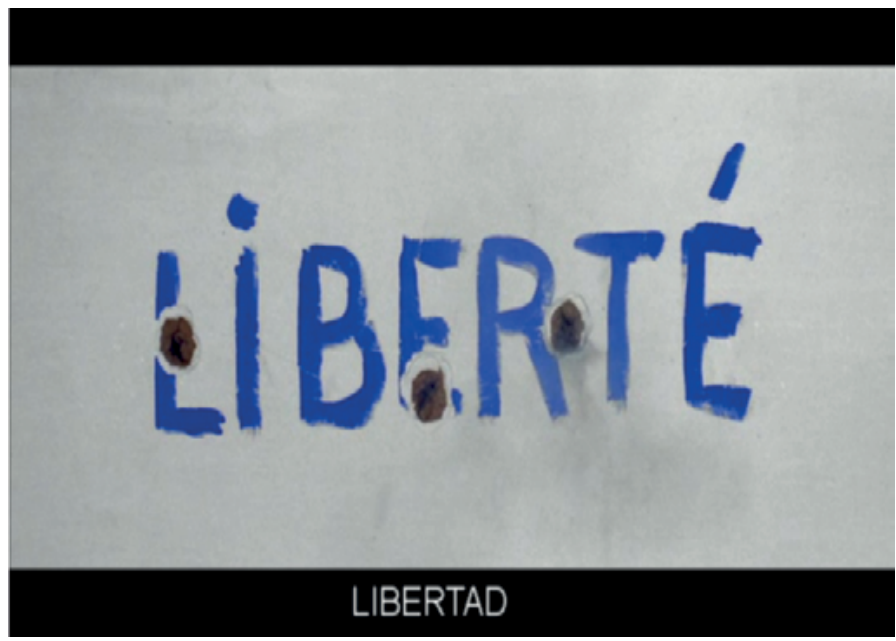

Figura 14

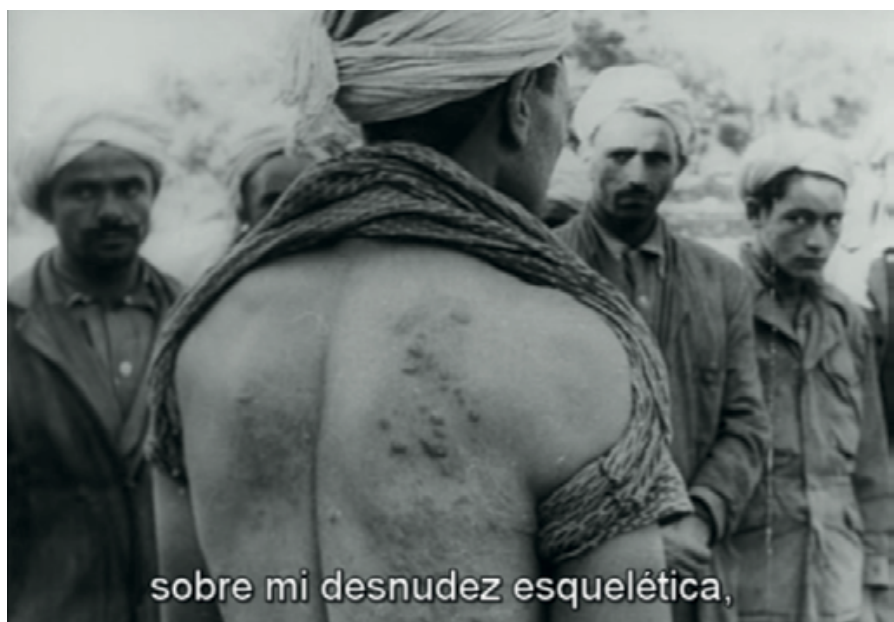

Figura 16 capacidades y actividades (ya sean de tipo creativo, sexual, ideológico, etc.). No está negando esa necesidad de emancipación humana cuando en Made in U.S.A Godard dispara sobre la palabra Libertad [Fig. 14], como haría Pasolini unos años antes en La Rabia al mostrar los cuerpos colmados de balazos de víctimas de la escabechina de Argelia mientras recitaba Libertad, el célebre y simbólico poema de Paul Éluard fechado en 1942 [Fig. 15] [Fig. 16]. O cuando en La gaya ciencia (Le Gai savoir, Jean-Luc Godard, 1969) escribe «ser libre» (être libre) en el sujetador de una bella modelo de lencería y lo monta junto a fotografías de víctimas del exterminio nazi y de la masacre de Vietman [Fig. 17]. En ninguna de las tres

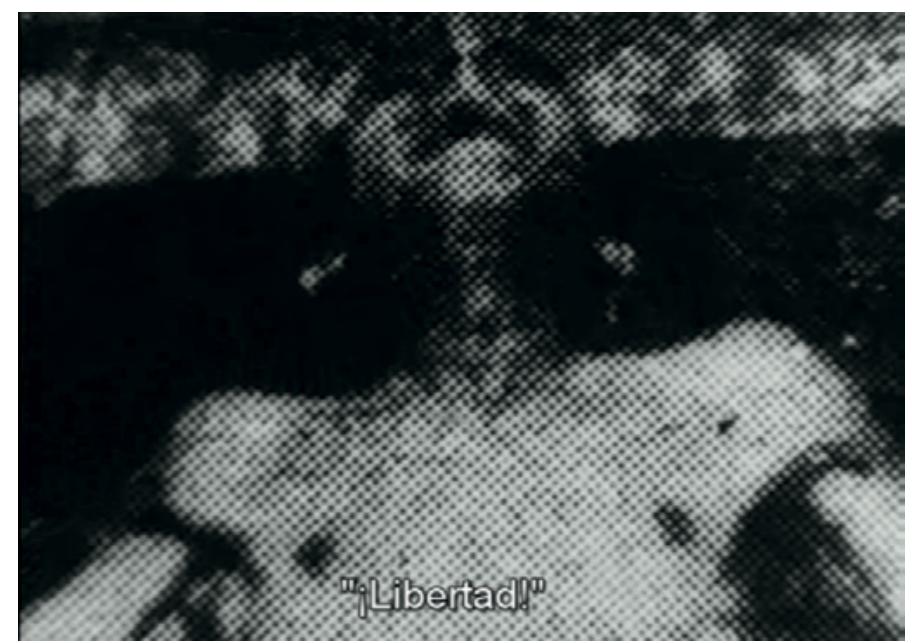

Figura 15

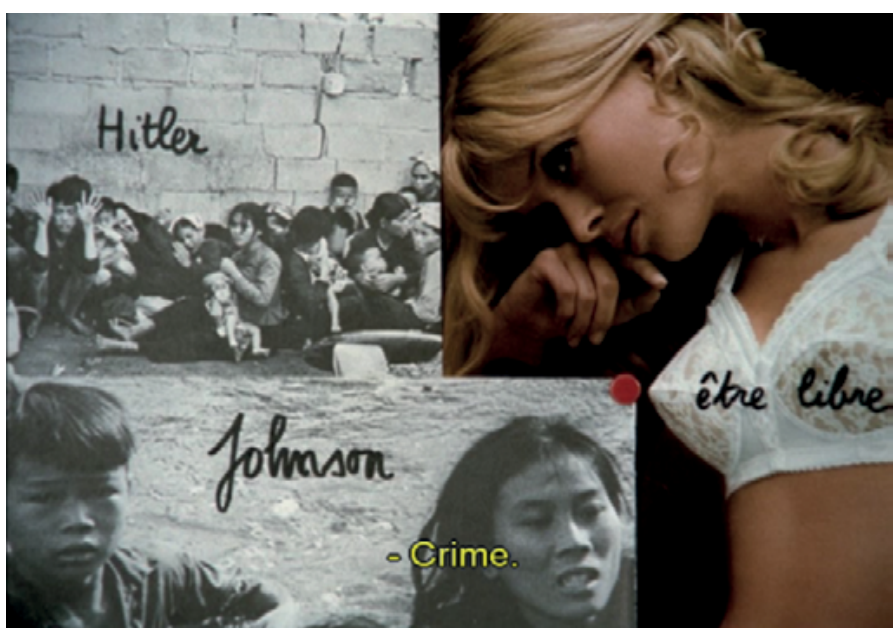

Figura 17 
fotografías encontramos a un ser libre, nos dice Godard, aunque la poca libertad de la que disfruta ella como representante de una sociedad de consumo (también de su cuerpo) parece haberse erigido sobre la desgracia de los otros. Desde luego que en estos ejemplos y en otros que podrían ser citados, no se trata de una negación de los poderes humanos. Y mucho menos en alguien como Godard que en sus primeros trabajos cinematográficos, imbuido por ciertas lecturas fenomenológicas, aboga por una libertad de la consciencia y el pensamiento y la imaginación sobre el mundo, incluso en las situaciones más banales — como se puede apreciar en la escena del metro en Banda aparte (Band à part, 1964) [Fig. 18] en la que los protagonistas se empeñan en producir una imagen distinta del espacio en el que se encuentran precisamente usando su libertad para mirar de un modo distinto, película por lo demás, consagrada a cantar al libre albedrío humano. Solo que en ciertos momentos, las cosas cambian, «las cosas son como son».

Más bien lo que ocurre en estos autores que viven en esta época tan convulsa, es que sienten la necesidad de preguntarse por las condiciones de posibilidad de dicha Libertad entendida en abstracto y sin contextualizar, si tal palabra es utilizada como arma política en la Guerra Fría o cuando funciona simplemente como un sustantivo que da un poco de lustre a su acompañante (libertad de mercado, libertad de consumo, libertad de explotación sexual, pero libertad made in usa, diría Godard sencillamente). Las atrocidades de la guerra de Argelia, aquella definida en El soldadito (Le petit soldat, JeanLuc Godard, 1963) como «una guerra sin convicción» y de tantas otras que recorrieron la década (Vietnam o Palestina-Israel, por no hablar de las dictaduras de América Latina) provocaron una brecha en el corazón del discurso humanista internacional, que chirriaba al ser cotejado con la actuación de los ejércitos y de los diplomáticos occidentales en terceros países ${ }^{6}$. Terminada la guerra, la filosofía que daba sustrato a ese pueblo ahora ausente, el humanismo, no tiene, a juicio de Henri Lefebvre, nada más que aportar que falsas doctrinas ofi-

${ }^{6}$ Véase (Ross, 2008: 90).

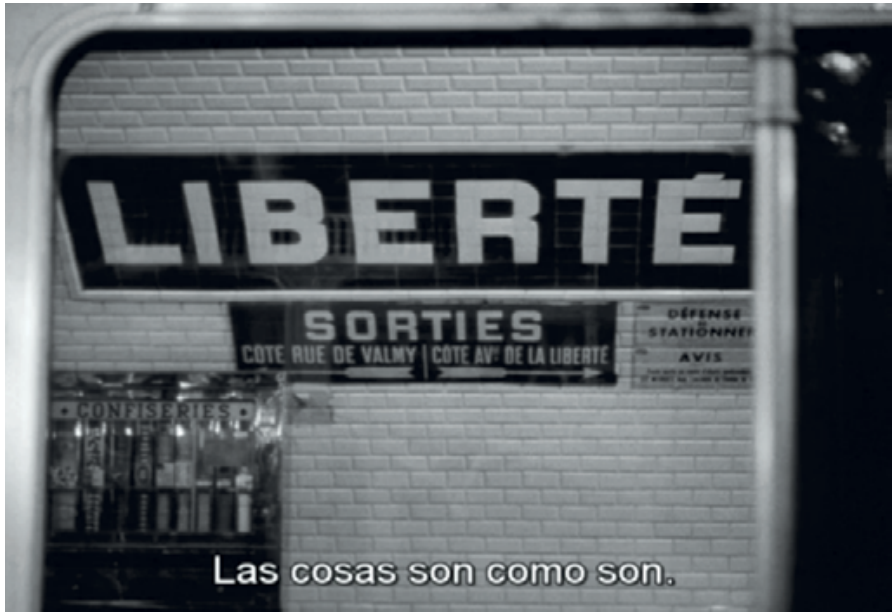

Figura 18

ciales y servir de entretenimiento para intelectuales de izquierda nostálgicos: «El viejo humanismo "clásico" hace tiempo que ha terminado, y mal, su carrera. Está muerto. Su cadáver, momificado, embalsamado, pesa y hiede. [...] El viejo humanismo encontró la muerte en las guerras mundiales, durante el aumento demográfico que acompaña a los grandes exterminios, ante las exigencias brutales del crecimiento y la competición económica» (Lefebvre, 1968: 125). En las pantallas de los cineastas más avezados lo que encontraremos será entonces, un compromiso absoluto por situar los elementos en su presente e ir a la raíz de las cosas. Y como la Paz o la Ocupación, ¿por qué no podríamos dudar de la Libertad?

Por todo lo dicho, como apunta Font, «la primera exigencia del nuevo cine [es] evitar la tabula rasa del pasado y abrir un estado de cuentas ficcional para entender las contradicciones del presente y orientarse en una situación política confusa» (Font, 2002: 167). Este modo de reflexionar no debía dejarse arrastrar por profecías sino tratar de volver a conectar la vida a la realidad con todas sus consecuencias para dilucidar qué había podido ocurrir. «Libertad», «pueblo», «paz», a todo había que darle una vuelta de tuerca. Entre tanto recelo se temió incluso que las mismas relaciones humanas estuviesen en peligro, que la desconexión entre sujetos hubiese alcanzado tal punto de crisis que se hubiese convertido en frío silencio o guerra desatada. La vida en sociedad 
también estaba en liza. Así pues, otra opción con la que contaban los cineastas además de la sospecha ante los grandes ideales era exhibir la violencia en crudo. Si el proletariado no iba a acabar con la burguesía, además de refugiarse en los más desheredados y en los individuos perdidos, también quedaba esperar a ver cómo esta se autodestruía a sí misma. O quizá ni tan siquiera esperar a que ocurriese sino fantasear con su posibilidad. Se suceden así los distintos films apocalípticos más o menos alegóricos o burlescos donde las clases medias se dan a sus bacanales de consumo que solo pueden terminar como el rosario de la aurora porque en ellas dan rienda suelta a sus pasiones mortíferas. Desde las fiestas decadentes y poco dulces de Fellini o incluso Warhol (que son la otra cara de aquellas fiestas de la incomunicación de Antonioni), los discretos pero perversos encantos de la burguesía de Buñuel, los puñetazos, las explosiones con sangre de bote y los carnavales atroces de Godard —-desde Pierrot el loco (Pierrot le fou, 1965) a Made in U.S.A (Made in U.S.A, 1966) o Weekend (Week-end, 1967) —, los atascos infernales que rueda Jacques Tati, las parejas en perpetuo conflicto entre sí en Fassbinder o directamente las orgías sádicas y ceremonias lacerantes como la que filmara Pasolini con Saló, o los 120 días de Sodoma (Salò o le 120 giornate di Sodoma, 1975), un exceso y una fuerza corrosiva saturan el cine moderno. Una ráfaga de agresividad que tendrá lugar en espacios igualmente inhumanos — que parecieran diseñados para tales hecatombes - lo recorre. No es casual que Godard entregue armas a cada vez más personajes de sus fábulas y ensayos fílmicos sobre la sociedad moderna, a niños, turistas, profesores, niñeras que las usan para matarse entre sí o tirotear al espectador y agujerear la pantalla de cine; o que la apatía y la tensión acumulada en el Antonioni de los sesenta acabe en hongo de fuego liberador con objetos de consumo volando por los aires en Zabriskie point, fechada justo en 1970. Esta es, por ejemplo, la idea que se desprende de un pasaje de los Cinétracts (Cinétracts, Marker, Garrel, Godard, Bonan, Fromanger, Gorin, Loiseleux, Raynal, Resnais, 1968) en la que se intercalan imágenes de manifestantes gravemente heridos por la policía porra en mano junto a unos cartones que irónicamente invocan: «En medio de la civilización moderna la (Ré)pública y la libertad serán aseguradas y el progreso y la independencia, y la paz habrán triunfado. Hace falta que viva la República y la Francia». El verdadero rostro de la paz y el consenso social, era una faz ensangrentada [Fig. 19]. El paso natural tras la desconfianza era la guerrilla.

A falta de la utopía, una creencia férrea en que, la sociedad entendida como una competencia entre sujetos esta acabaría por descomponerse rápidamente y deshacer al sujeto, podía servir para paliar un poco la desesperanza y ver con más tino la realidad. No faltarán las distopías si no como forma de redención sí al menos como manera de mostrar la violencia latente

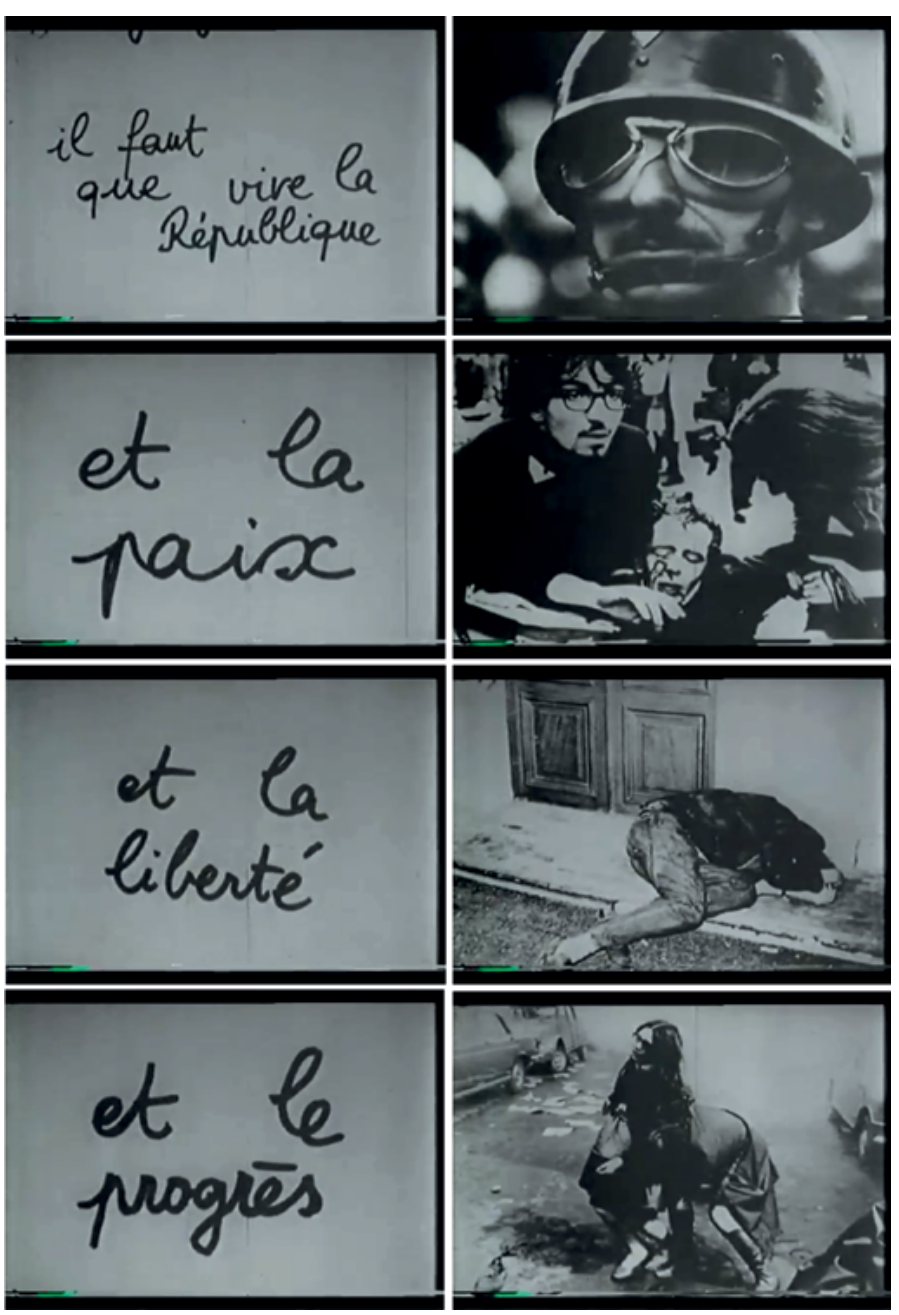

Figura 19 
que irá in crescendo y que no podía hacer sino explotar a partir del 68. En consecuencia durante los sesenta los intelectuales sellarán una alianza con lo marginal frente al consenso generalizado y el aburguesamiento de los trabajadores y ante ese «hombre» en abstracto y sin historia que predicaban ciertas corrientes humanistas. Con mucha menor frecuencia encontraremos cantos a las masas de trabajadores pobres como ocurriera en la inmediata posguerra - y cuya mejor traducción en el plano fílmico fue el Neorrealismo italiano- ya que lo frecuente será un interés ascendente por aquellos que quedan en las lindes de la sociedad y cuyas vidas están fuera de los esquemas impuestos.

Los viejos lazos con la realidad se han diluido, de que ya no existen los grandes héroes ni las historias trascendentes sino esta amalgama de alteraciones que requieren ser pensadas y a las que solo queda mirar con los ojos de aquellos que más las sienten en su carne: el proletariado urbano, el desarraigado, el antihéroe, sin clase y sin fronteras, las mujeres siempre subalternas, el personaje anónimo, o con la mirada de una colectividad presa de la realidad cotidiana y perdida en un tiempo y un espacio que empiezan a serle ajenos. Sobre Banda aparte dirá Godard: «Son personas que son reales, y es el mundo el que hace banda aparte. Es el mundo el que no es sincrónico, ellos son justos, son verdaderos, representan la vida. Viven una historia simple, es el mundo alrededor de ellos el que vive un mal guión» (tomado de Aidelman y De Lucas, 2010: 229). Desde Monsieur Hulot a los sujetos vaporosos de Antonioni, las marginales y traumatizadas figuras del cine alemán y sueco, los jóvenes de vidas maltrechas de la cinematografía inglesa, los alternativos del underground neoyorquino o los rebeldes del nuevo cine latinoamericano, a los personajes del cine moderno el mundo se les ha hecho duro, se les ha hecho extraño. Es entonces cuando se impondrá la necesidad de rehacer las formas de socialibidad y de vida en común para que esta no acabe en neurosis o batalla sangrienta del todos contra todos. Aunque para ello hubiere que seguir mirando atrás o, por ejemplo, dirigir el foco hacia «otros pueblos» no contaminados por el veneno del progreso.
Pues, en efecto, mientras los solemnes pueblos nacionales de Europa se extinguían y sus grandes ideales se daban de bruces contra su propia memoria, a comienzos de los sesenta el Tercer Mundo hablaba de otros pueblos y sujetos. O como diría el poeta italiano, también en La rabia, «un nuevo problema estalla en el mundo, se llama Color [...] Otras voces. Otras miradas. Otros bailes. [...] Debemos aceptar que hay infinitas vidas que quieren, con inocente ferocidad, entrar en nuestra realidad». Desde mediados de los cincuenta y con una fuerza que no se disipará hasta bien entrados los setenta, en Occidente, los terceros países adquirieron un valor primordial a la hora de adoptar una postura de una oposición al sistema. Un primitivismo entusiasta recorrió la década. Muchos alzaron la vista fuera e identificaron que felizmente en estos pueblos y en sus movimientos de liberación había un rechazo a aquellos principios que ahogaban a los países más enriquecidos. Como advierte Hal Foster «este desplazamiento es propio de la posguerra y de la resistencia del tercer mundo y está claramente relacionado con la politización de muchas disciplinas» (Foster, 1985: 45-70). En Cuba sí (1961), uno de los documentales poéticos en los que Marker viaja con su cámara por un Pequeño planeta que está perdiendo sus bordes, la voz del narrador observa: «¿De qué está hablando la gente en el mundo en este momento? De la gente, de los países y de animales fabulosos, de Argelia, de Francia, de América, del espacio, del tiempo, del Congo, de Laos, de África y de formas que tomarán durante la segunda mitad de este siglo, la violencia y la plegaria. El Apocalipsis también estaba escrito. Era el libro más caro del mundo. Fue entonces cuando en el mundo nos pusimos también a hablar de Cuba». Estos espacios y sujetos periféricos se convertirán pronto en referencias ideológicas más que geográficas. A medida que pasen los años sus rasgos «otros» harán de ellos objetos de un interés cada vez más intenso, pues serán percibidos como terceros espacios, focos de resistencia y posos de energía alternativa. Y sobre todo, sabremos que ese color, como argumentaba James Baldwin, «no es una realidad humana o personal, es una realidad política» (Baldwin, 1963: 88). 
En todo caso una pregunta flotaba en el aire: «¿qué es el pueblo?», o mejor dicho «¿podemos aún hablar de la existencia de un pueblo?». Sin duda alguna esta cuestión está en el centro de las preocupaciones de intelectuales y creadores, sus ecos resonarán a todo lo largo de la década y hasta en los setenta y por supuesto se encuentra detrás de un entendimiento distinto de la Historia que ya no seguirá ninguna línea recta hacia su resolución (pues esta no parecía llegar o si se la seguía acabaríamos como los personajes de Pasolini, muertos al final del camino), sino que desde entonces, la Historia se bifurcará tantas veces como pueblos, minorías y voces existen. A pesar de que dicha pregunta suscitó las respuestas más variadas (el pueblo como proletariado urbano, el pueblo como conjunto de oprimidos y marginales, el pueblo como el otro que no somos o la desaparición del pueblo), una cosa parecía estar clara: para responder a dicha cuestión era necesario reformular, cuando no hacer caer, la visión del sujeto trascendental, el modelo de sociedad individualista y su historicidad teleológica para arribar a otra noción de sujeto y de vida en común, así como a otras temporalidades posibles. En alguna ocasión Deleuze, que sintió un enorme respeto por el cine moderno y su propuesta política, situó al filósofo y al artista en el mismo plano compartiendo un sufrimiento común y una tarea titánica:

Carecemos de resistencia al presente. La creación de conceptos apela en sí misma a una forma futura, pide una tierra nueva y un pueblo que no existe todavía [...]. El arte y la filosofía se unen en este punto, la constitución de una tierra y de un pueblo que falta. [...] Tienen en común la resistencia, la resistencia a la muerte, a la servidumbre, a lo intolerable, a la vergüenza, al presente.

(Deleuze y Guattari, 1993: 110-111)

Lo que acabó con las esperanzas de la toma de conciencia fue justamente la toma de conciencia de que no había pueblo, sino siempre varios pueblos, una infinidad de pueblos, que quedaban siempre por unir o bien que no había que unir.

En el cine clásico el pueblo está ahí, aun oprimido, engañado, sojuzgado, aun ciego o inconsciente. [...] En el cine americano, en el cine soviético, el pueblo está ya ahí, real antes de ser actual, ideal sin ser abstracto. [...] Pero muchos factores iban a comprometer esta creencia [...] En síntesis, si hubiera un cine político moderno, sería sobre la base: el pueblo ya no existe o no existe todavía... «el pueblo falta».

(Deleuze, 2015: 286-287)

Y lo hubo. A pesar de que en este artículo nos hayamos quedado en el lado sombrío de la Historia, ciertamente, los artistas habrían de hacer emerger algo, otra cosa, a partir de lo que ya les es dado, a partir de lo que falta. Pero principalmente, se verían en la tesitura de aceptar que todo, desde el sujeto al tiempo y la vida, se hace plural y está en liza. «Mis películas —afirmaba Godard - se inscriben en una corriente de la izquierda europea que va de derrota en derrota, en una hermosa corriente romántica [...] En cierta manera, el cine ha sido siempre una operación de duelo y de reconquista de la vida» (tomado de Aidelman y De Lucas, 2010: 335-336). El cine moderno en Europa se caracterizó entonces por un fuerte deseo por interrogar, experimentar con y vivir una realidad que en el fondo dejaba la puerta abierta a la posibilidad de rehacerlo todo (tanto en el cine como en la «vida»). Había llegado el momento de rehacer principios (políticos y poéticos) que daban por asentados, luchar contra sus propios conceptos, ponerlos en el tiempo. Por eso Marker, después de haber reflexionado durante casi dos horas, concluye Le Joli Mai haciendo una oda a la libertad, ahora sí, ya no como algo trivial sino como una conquista, como una aptitud de aquellos hombres que «son capaces de interrogar, de rechazar, de abordar, de pensar o simplemente de amar».

\section{Bibliografía}

Aidelman, Núria y De Lucas, Gonzalo (ed.) (2010), Pensar entre imágenes. Conversaciones, entrevistas, presentaciones y otros fragmentos, Barcelona: Intermedio.

Baldwin, James (1963), The Fire Next Time, Nueva York: Penguin Books.

Baudrillard, Jean (1970), El sistema de los objetos, México: Siglo XXI. 
BELL, Daniel (1992), El fin de las ideologias. Sobre el agotamiento de las ideas políticas en los años cincuenta, Madrid: Ministerio de Trabajo y Seguridad Social.

Deleuze, Gilles (2015), La imagen-tiempo. Estudios sobre cine 2, Barcelona: Paidós.

Deleuze, Gilles y GuatTari, Felix (1993), ¿Qué es la filosofía?, Barcelona: Anagrama.

Font, Domènec (2002), Paisajes de la modernidad. Cine europeo, 1960-1980, Barcelona: Paidós.

Foster, Hal (1985), «The "Primitive" Unconscious of Modern Art», October, 34, págs. 45-70.

Huyssen, Andreas (2006), Después de la gran división. Modernismo, cultura de masas, posmodernismo, Buenos Aires: Ana Hidalgo.

Lefebvre, Henri (1968), El derecho a la ciudad, Barcelona: Ediciones 62.
Marcuse, Herbert (1953), El hombre unidimensional. Ensayo sobre la ideología de la sociedad industrial avanzada, Barcelona: Planeta Agostini.

Núñez Laiseca, Mónica (2006), Arte y política en la España del desarrollismo, Madrid: Consejo Superior de Investigaciones Científicas.

Pasolini, Pier Paolo (1997), La religión de mi tiempo, Barcelona: Icaria.

Ross, Kristin (2008), Mayo del 68 y sus vidas posteriores. Ensayo contra la despolitización de la memoria, Madrid: Antonio Machado Libros.

Valle Corpas, Irene y Arozamena, Alejandro (2018), «Leer/ ver dos veces hasta olvidar: elementos alegóricos y falso documental en Hiroshima mon amoun, Hugo López Castrillo y Pedro José Mariblanca (ed.), Olvidar/Forgetting- Brumaria Works \#9, Madrid: Brumaria, págs. 671-693. 